\title{
The man from the biosphere - exploring the interaction between a protected cultural landscape and its residents by quantitative interviews: the case of the UNESCO Biosphere Reserve Rhön, Germany
}

\section{Tobias Behnen}

Keywords: residents of protected areas, human-environment interaction, Central German Uplands, Biosphere Reserve Rhön

\section{Abstract}

The Rhön is a sparsely wooded central German upland and an historical cultural landscape which has been protected as a biosphere reserve since 1991. This status has induced a positive change through adapted landscape conservation and support of endogenous economic processes. Quantitative interviews with residents were carried out to determine the relevance of their relationship with the landscape. The survey shows that the biosphere reserve is a preferred rural habitat and that the local population is keenly aware of it and accepts it. The variety of uses, however, also creates difficulties and conflicts, e.g. in the high number of out-commuters. A remarkable result is the positive influence of the biosphere reserve on the sense of cohesion in the region which traditionally suffers from multiple divisions.

\section{Profile}

Protected Area

UNESCO Biosphere Reserve Rhön

Mountain range

Central German Uplands

Country

\section{Germany}

\section{Introduction}

It has become quite popular to apply empirical social research methods in the analysis of protected areas. In national parks, visitors have been repeatedly interviewed (Job 1996; Leitinger et al. 2010; v. Ruschkowski 2010; Sieberath 2007). In biosphere reserves, the inhabitants are additional key actors. Their perception, opinion and behaviour is of equal importance to that of the visitors. In biosphere reserves, settlements are expressly included, which means that the acceptance by the inhabitants of the protected area, its conservation and development aims and the instruments applied to attain them are elementary factors for the long-term success of the protected area (Schaal 2009; Stoll 1999). A number of theoretical, quantitative and qualitative investigations into this subject have been published (e.g. Berghoefer et al. 2010; Karthäuser 2009; Schieber 2009; Wallner et al. 2007; Weixlbaumer \& Coy 2009). Findings from environmental psychology are also very valuable (e.g. Carrus et al. 2005; Hofinger 2001). In a more geographical attempt, questioning of the inhabitants should focus more intensely on the role of the landscape to find out which part of it or what kind of spatially relevant behaviour strengthens or weakens the acceptance of the protected area. Obviously, the regional identity of the inhabitants, perceptions of the landscape, environmental concerns and especially mobility behaviour in the mountainous regions of European industrial states play an important role here. It is not the aim of this paper to prove or evaluate the complex causal chains, rather it focuses on identifying determining factors of this special human-environment interaction, taking Rhön Biosphere Reserve (BR) as a case in point. The central question is: How do the residents' thinking and actions relate to the landscape

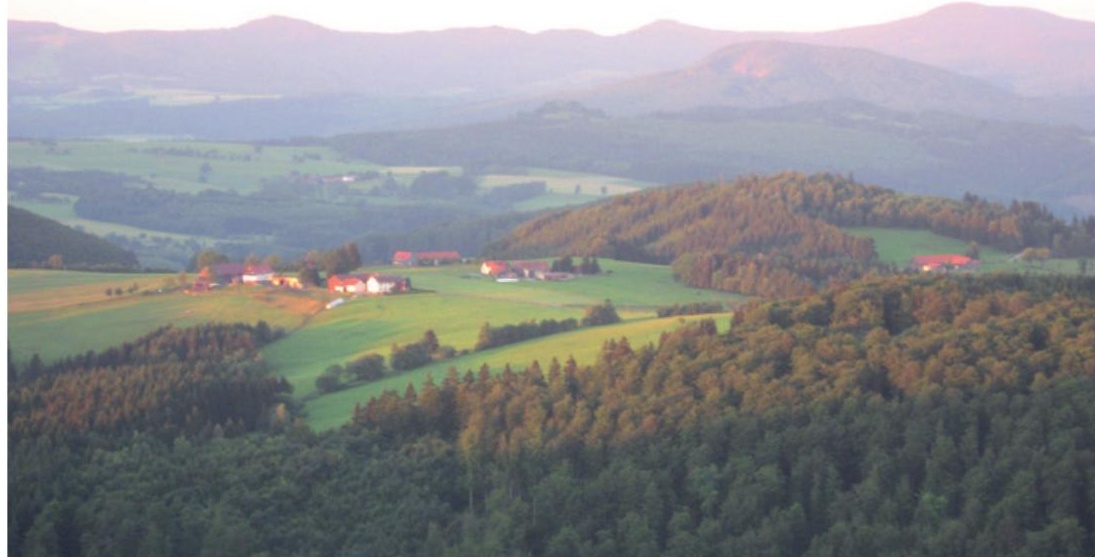

Figure 1 - Typical part of the Rhön with a combination of grassland (esp. mat-grass), grazing land and forest (site-adapted beech forest but also spruce monoculture). (C) T. Bebnen

of the protected area and its objectives? In addition, I shall put the results of the case study in the context of other surveys.

\section{Study area}

The character of the landscape of the Rhön is captured by its byname land of open distances. In contrast to neighbouring regions, the Rhön is sparsely wooded, forest cover amounts to only $40 \%$. The numerous woodless hilltops (up to $950 \mathrm{~m}$ at the Wasserkuppe: $50^{\circ} 29^{\prime} 5^{\prime \prime} \mathrm{N}, 9^{\circ} 56^{\prime} 1^{\prime \prime} \mathrm{E}$ ) allow views over the varied historical cultural landscape (Figure 1).

Today, the residents and tourists perceive the Rhön positively as an original European agricultural landscape - a dreamscape. But it should not be forgotten that in the past the region was characterized by poverty, famine, low mobility and social inequity (Dix 2003). To this day, the socio-economic situation includes fea- 


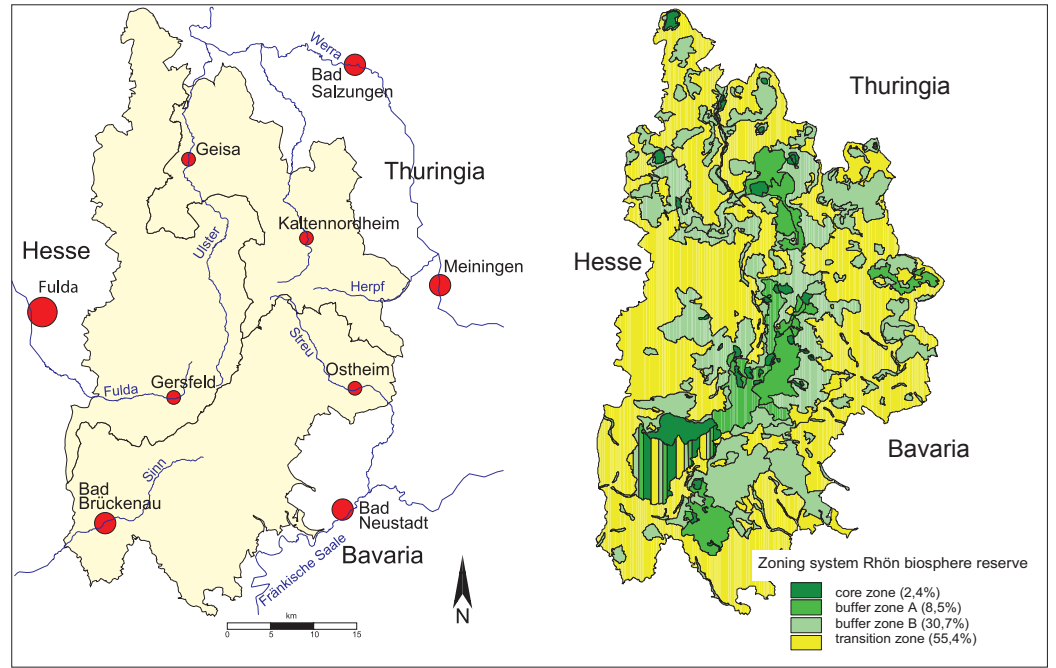

Figure 2 - Rhön BR. (C) GIS-Zentrale Biosphärenreservat Rhön modified

tures of considerable rural deprivation. Nevertheless, the residents have been and still are strongly attached to the region where the Christian faith still plays an important role. However, the Rhön is also known for its pronounced intraregional heterogeneity: e.g. valley vs. mountain villages, more affluent vs. poor areas, predominantly Catholic vs. Protestant villages, communities with Christian Democratic vs. such with Social Democratic majorities, areas with growing vs. those with declining population. There are also many different idioms but the administrative segmentation plays the crucial role. Territorial borders have changed in the past, but today the boundaries of the federal states of Bavaria, Hesse and Thuringia, which follow the main watersheds, divide the Rhön into its three best-known parts. This division encourages a centrifugal orientation on central locations. The topography is another barrier between the three parts. Considerable altitudinal differences have to be crossed within short distances.

Since 1991, large parts of the Rhön have been protected by the BR (Figure 2). It stretches over 185000 ha and has 162000 residents $\left(88\right.$ per $\left.\mathrm{km}^{2}\right)$. Administrative responsibility is shared by the three federal states involved. The BR has three administrations which successfully coordinate and support landscape maintenance and preservation, endogenous economic development, adapted tourism and environmental education. In contrast to other biosphere reserves (e.g. Entlebuch BR in Switzerland), however, civic participation in the Rhön remained low during the foundation phase.

\section{Survey design}

From 2005-2009, the author undertook quantitative research in the Rhön on four topics: regional identity, cultural landscape change, environmental behaviour and mobility behaviour. More than 2500 face-to-face interviews with residents (minimum age: 14 ) from all three parts of the BR (Bavaria, Hesse, Thuringia) were conducted. They took place in supermarkets which had proved feasible for this purpose. They were scheduled for November to avoid interviews with tourists. The standardized questionnaires included more than 30 questions and the data were evaluated using SPSS.

\section{Results}

The survey results from the Rhön are structured along the generalized aspects of interaction mentioned in Figure 3. On the one hand, residents interact with the BR by perceiving and accepting the protected landscape, using it for private or commercial purposes and acting in ways which support or inhibit its objectives. On the other hand, the BR can affect their attitudes and behaviour and possibly their regional identity. Human-environment interaction is complex and certainly has many more dimensions, as the theories and findings from human ecology show (Weichhart 2007). For the inductive model used here, the selected aspects were to display the specific regional relationships within a protected historical cultural landscape. Therefore topics which are not directly landscape-related, such as climate change, or which are non-regional, such as globalization processes, were not considered.

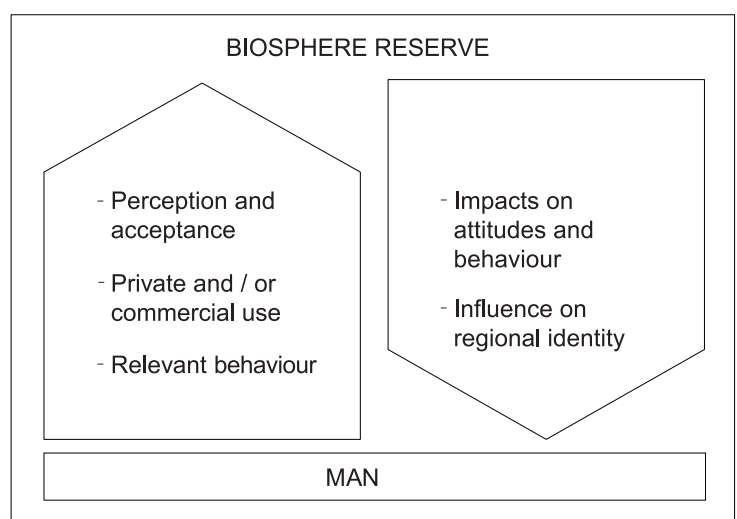

Figure 3 - Aspects of the human-environment interaction discussed in Rhön BR.

\section{Perception and acceptance}

Dependent on their place of residence within the protected area, the local population is more or less intensely and consciously aware of the BR as landscape and as institution. Residents form their opinion as subjects of acceptance about the object of acceptance on the basis of their everyday experience and through media information. Most of the interviewed residents had been in contact with the BR for quite a long time because $76 \%$ of them had lived within the Rhön for more than 20 years and individual home ownership is very high ( $80 \%$; Germany: $52 \%$ ).

There is a substantial acceptance by the local population of the BR. About three quarters of the interviewees said that it is fulfilling its task by protecting the landscape and enabling human use at the same time. Residents who use the landscape for agricultural pur- 
poses largely share this acceptance even though they have to accept restrictions that come with the BR. By comparison, residents who do not use the landscape for recreational purposes show a lower degree of acceptance (only 50\%).

The more personal question about the acceptance "How important is the BR for you?" results in a high percentage for "very important" or "important" (72\%). The rate for men $(69 \%)$ is slightly lower than that for women $(73 \%)$ and the result of the younger $(<20$ years old: $83 \%)$ and older interviewees (>60: 76\%) is higher than that of the other age groups. It is remarkable and a typical feature of the Rhön that the reunification of Germany and of the Rhön in particular $(76 \%)$ was ranked as more important than the biosphere reserve by its inhabitants.

The preservation of the typical anthropogenous open landscape of the Rhön can only be ensured if farmers are paid for maintenance measures. The vast majority of the interviewees (89\%) agree with these payments which confirms the general acceptance.

The residents' intense awareness of the BR could be proved by an open question. They are sensitive about changes or disturbances of the landscape, e.g. by environmental pollution, traffic or tourism. In this context, several people showed a lack of understanding concerning the deforestation of spruce monocultures even though this measure is consistent with the aims of the BR (Figure 4). A more offensive information policy on the part of the BR management could lead to a better understanding of such measures. $70 \%$ of the Rhön residents gain information about the BR from daily newspapers, despite increasing importance of electronic media. In general, $71 \%$ of the interviewed people rate all offered information as "very good" or "good".

\section{Private and / or business use}

The perception and acceptance of the BR Rhön can be seen in context with the residents' use of the landscape. $94 \%$ of them use the landscape for recreational purposes, $17 \%$ for commercial purposes. Most people experience the landscape in company. Hiking is the dominant activity (83\%) (Figure 5), which is not only environmentally friendly but also encourages ecological awareness in general (Brämer 1998).

The interviewees stated that they spend plenty of time within the landscape: $52 \%$ up to one hour per day (average), about $25 \%$ up to two hours and $16 \%$ even longer. Membership of landscape-related groups like the Rhönklub or sports clubs also plays an important role $(23 \%)$. The survey shows that participation depends on age, sex and origin. While $52 \%$ of Bavarian men of 60 or older are members of such groups, only $3 \%$ of Thuringian women between the ages of 20 and 39 are organized in this way.

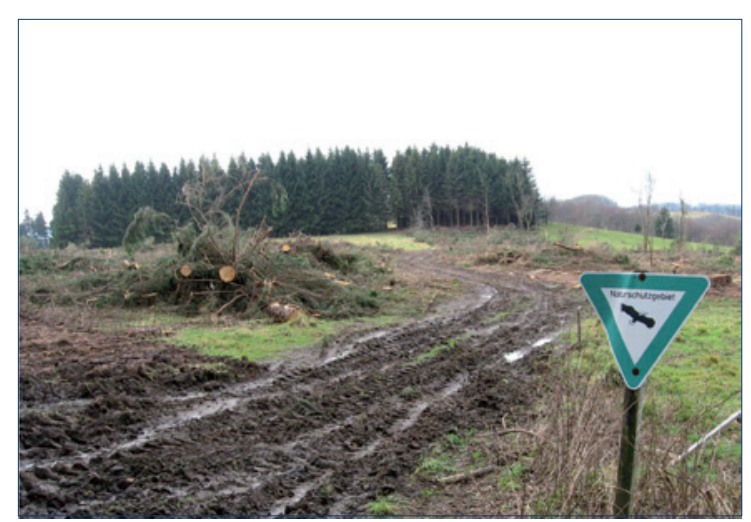

Figure 4 - The felling of non-native spruces in a nature reserve on the Wasserkuppe was not accepted by parts of the local population. (C) T. Behnen

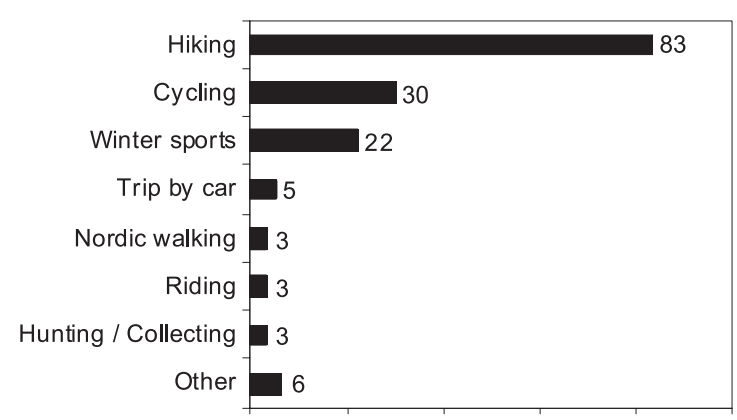

Figure 5 - "When using the landscape for recreational purposes, which activities do you prefer?" (\%, author's survey 2006, $n=669$, multiple answers possible).

\section{Relevant behaviour}

A typical example from the Rhön of environmentally friendly behaviour that supports the aims of the BR is the consumption of regional food by the residents. $70 \%$ of the interviewees said that they deliberately buy food produced within the region, especially meat and milk products, eggs and baked goods (Figure 6). The preference for regional food correlates with the opinion about the importance of the protected landscape. Residents who rated the BR as "very important" for them favour regional food more often (82\%) than those who answered "important" (74\%), "less important" $(60 \%)$ or "not important" (41\%).

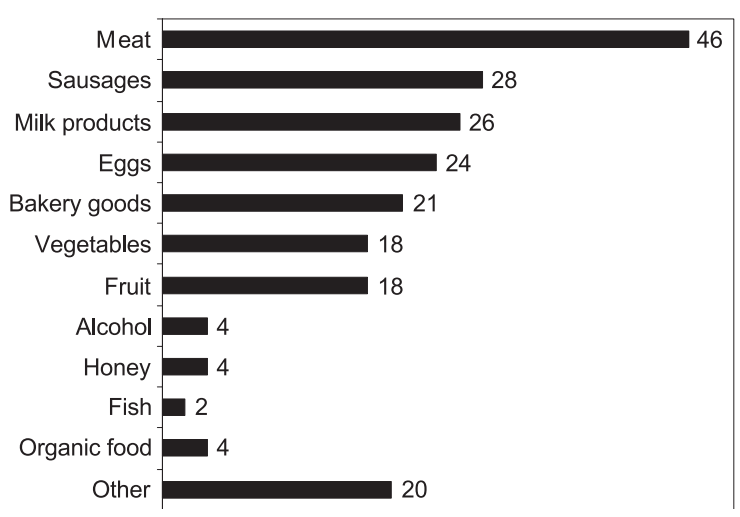

Figure 6 - "Which regional food do you buy deliberately?" (\%, author's survey 2006, $n=450$, multiple answers possible) 
Two additional questions yielded one third of respondents in favour of increasing the range of regional food and especially organic food on offer. It is not clear whether this implies real market potential because a question about the willingness-to-pay was not part of the questionnaire. Moreover, $77 \%$ of the house owners within the BR grow their own fruit and vegetables.

It is on the issue of mobility behaviour that the local population comes in conflict with the aims of the BR. Their affinity with the region and their personal roots induce high rates of daily long-distance commuting. The survey shows that $91 \%$ of the residents who say that they and their families suffer from long daily commuting times accept this burden just to avoid moving house. Only 14\% had already thought about relocation even though for $54 \%$ the travel costs are a substantial problem and $85 \%$ agree that they cannot spend enough time with their families and friends and in clubs or associations due to the long travel times. This situation is not only a burden for the commuters but also for the villages and the vulnerable mountain landscape due to the noise and emissions caused by road traffic. The percentage of interviewed adults with a driving license $(90 \%)$ is only slightly higher than in the rest of Germany (88\%, infas/DLR 2010) but the rate of people without a car at their disposal is very low (6\%; Germany: 18\%, infas/DLR 2010). $57 \%$ of all residents of the BR commute on weekdays for business or educational purposes. $25 \%$ of them travel for longer than 30 minutes. The preferred mode of transport is the car $(77 \%)$. The attitude of the residents towards road traffic is ambivalent. $52 \%$ support the construction of new roads within the BR but more than two thirds agree that road traffic has become a burden for the region. $62 \%$ agree with the statement that this burden should be reduced, especially in a BR. About three quarters agree that public transport, which is hampered by the administrative division of the Rhön, should be enhanced.

Impacts on attitudes and behaviour

A conscious relation between the BR and the personal environmental behaviour of the residents cannot be confirmed. Only 19\% affirm the corresponding question. They specify for example that they particularly respect the rules for nature protection, e.g. that they keep to the hiking trails. The author presumes that the protected landscape has an unconscious influence on the behaviour but further research should be undertaken to investigate this.

Influence on the regional identity

It seems obvious that the regional identity plays an important role for the successful implementation of the conservation and development objectives of the BR but at the current point of research this statement could not be proven. Scientific debate is consolidating (Schaal 2009) but we still need to discuss if and to what extent protected areas could create regional identity (Behnen 2008, 2009; Kühne \& Behnen 2006; Ipsen 1993; Mose 2009; Wittmann 2006).

Initially, the questions to the residents aimed at finding out with which region they identified most. The results show that the residents of the Rhön relate to competing regions (Figure 7). 39\% just said "Rhön", but almost the same number of interviewees answered "Bavarian Rbön", "Hessian Rbön" or "Thuringian Rbön". Other geographical units were also mentioned. For a high percentage of the residents, the BR has helped to reduce the effects of the topographic and administrative segmentation of the region and this percentage has grown constantly (2005: 49\%, 2006: 52\%, 2008 : 65\%, 2009: $72 \%$ ).

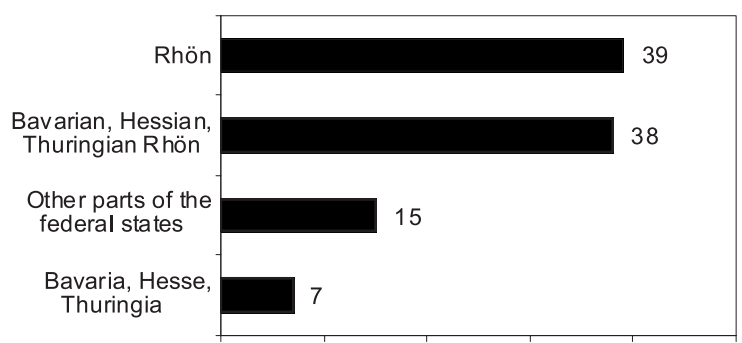

Figure 7 - "In which region do you live?" (\%, author's surveys 2005 and 2006, $n=1391$ )

The main reasons for a sense of belonging to the region are obvious aspects of socialization, such as "I grew up there" (62\%) or "My place of residence", but these are closely followed by mentioning "Landscape" (41\%). Socio-cultural features like dialect or traditions play a role but they are mentioned less often. Additionally, an open question shows that specific mountains, animals or plants are of great importance for the residents. In Hesse, the Wasserkuppe peak is named quite often. It is not only the highest peak of the Rhön but also the central tourist honey pot (Figure 8). The main living icon for the regional image is the breed of sheep called Rhönschaf. It has been successfully re-established as the multifunctional grazer supplying wool and meat but it also preserves the cultural landscape by reducing scrub encroachment.

\section{Discussion}

The results of the survey show that the residents of the Rhön BR feel very attached to the landscape and also to the aims of the protected area. For the protection it is particularly relevant that a high rate of the local population accepts the BR, e.g. by agreeing that farmers are paid for landscape maintenance. For the sensitive perception of the landscape it is important that the residents use it regularly and with awareness. A direct influence of the BR on the environmental behaviour could not be proven but local food identity (Everett $\&$ Aitchison 2008) plays an important role. For the development aims it is positive that the regional food products are not only niche products. 
Across the world, the Rhön is seen as a benchmark for biosphere reserves but there are also substantial negative impacts caused by the residents. Mobility behaviour dominated by cars goes against the objectives of the BR. It damages the environment but, paradoxically, is the effect of the otherwise desirable rootedness of the local population in the region. However, the growing identification with the Rhön as a whole can be put down to the existence of the BR.

The comparison with surveys undertaken in other mountainous protected areas is not easy. Scientific approaches differ greatly, dependent on specific research aims and related issues, such as perception, acceptance, public image vs. self image, regional identity or participation. Methods also vary considerably: standardized surveys (written, over the phone or face-to-face) with different types of questions and given answers as well as narrative interviews or mental maps. Additionally, regional peculiarities may be taken into account, such as the topics regional food and mobility behaviour in this study. It should be added that the comparison with national parks is not without problems as most of them contain few or no settlements. Nevertheless, because of the available data about national parks, some comparisons can be drawn. Acceptance of the protected area Rhön BR stands at a relatively high rate of $71 \%$ ("very important" or "important"). Stilfserjoch National Park (Italy) however, has only 58\% "supporters" (Leitinger et al. 2010), Harz National Park (Germany) 59\% ("agree" or "rather agree", v. Ruschkowski 2009) and the Großes Walsertal BR (Austria) 84\% ("very useful" or "useful", Rumpolt 2009). 93\% of the residents see the new Schwäbische Alb BR (Germany) as "positive" or "rather positive" (Schieber 2009).

The rate of $93 \%$ of the interviewees for whom the landscape of the Rhön is "very important" or "important" corresponds with the answers to a similar question asked in the Großes Walsertal BR (85\%).

Concerning the information about protected areas, Job (1996) and v. Ruschkowski (2009) investigated the dominant role of daily newspapers in the Harz $\mathrm{Na}$ tional Park. Daily newspapers also dominate information in the Rhön but the quality of the information was seen as better. $71 \%$ of the answers were "very good" or "good" against lower rates for the Harz (v. Ruschkowski 2009: 37\%; Job 1996: 53\%). Job’s hypothesis (1996) that less informed residents show a lower acceptance could be confirmed in most parts.

The outdoor leisure behaviour of the residents of the Rhön and the Harz is quite similar. In both regions, hiking is the dominant activity in the landscape (v. Ruschkowski 2009). The higher acceptance of the protected area by persons who use the landscape for recreational purposes, which was proved by Job (1996) in the Harz, could be confirmed in the Rhön as well.

The research about the Rhön BR resulted in a number of useful transferable findings. These could also be understood as management implications for other biosphere reserves or national parks:

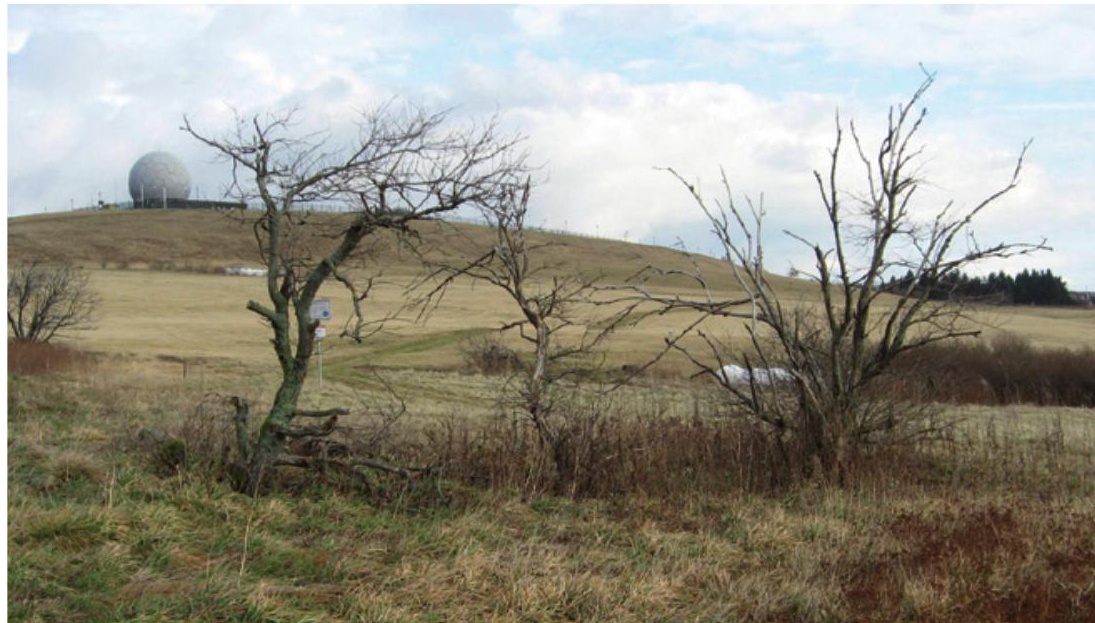

Figure 8 - The Radom on the Wasserkuppe, a legacy of the Cold War that became the main landmark of the Rhön. (C) T. Bebnen

It became obvious that a protected area will benefit from the promotion of the environmentally friendly use of the landscape by the residents. Acceptance will grow and behaviour that runs against the conservation aims will be reduced.

Another striking finding concerns the marketing of regional food. The saying "The way to a man's heart is through his stomach" sounds simple but it could be an effective way to support the regional identity through an everyday activity.

In terms of information about the protected area, the administrations should remember that they have two target groups interested in the landscape: tourists and residents. The best way to inform the local population about protection or development aims and concrete measures are daily newspapers.

However, it should not be forgotten that the definition and support of an ideal resident of a protected area who is well informed, consumes only local food and prefers traditional outdoor activities runs the danger of excluding people with a different landscape-related behaviour.

\section{References}

Behnen, T. 2008. Durch Redesign zu mehr Regionaler Identität: Die Rhön und andere Biosphärenreservate als Impulsgeber für den Biosphärenpark Neusiedler See. Beiträge Region und Nachbaltigkeit 5: 83-88.

Behnen, T. 2009. The role of regional identity in protected areas: the Biosphere Reserve Rhön (Germany) as benchmark. In: $4^{\text {th }}$ Symposium of the Hohe Tauern National Park for Research in Protected Areas (Conference Volume): (September 17-19, 2009, Kaprun Castle): 25-27.

Berghoefer, U., R. Rozzi \& K. Jax 2010. Many eyes on nature: diverse perspectives in the Cape Horn Biosphere Reserve and their relevance for conservation. Ecology and Society 15, 1. Available at: http://www.ecologyandsociety.org/vol15/iss1/art18 (accessed: 15/01/11) 
Brämer, R. 1998. Landschaft zu Fuß erleben. Brauchen wir gesondert ausgewiesene Naturerlebnisgebiete? Natur und Landschaft 73 (2): 47-54.

Carrus, G., Bonaiuto, M. \& M. Bonnes 2005. Environmental Concern, Regional Identity, and Support for Protected Areas in Italy. Environment and Behaviour 37: 237-257.

Coy, M. \& N. Weixlbaumer 2009. Die Untersuchungsergebnisse und ihre Bedeutung für die künftige Entwicklung des Biosphärenparks Großes Walsertal - Zusammenfassung und Interpretation. In: Coy, M. \& N. Weixlbaumer (eds.), Der Biosphärenpark als regionales Leitinstrument - Das Große Walsertal im Spiegel der Nutzer: 95-108. Innsbruck.

Dix, A. 1993. Vorindustrielle Kulturlandschaften Leitlinien ihrer historischen Entwicklung. In: Bayerl, G. \& T. Meyer (eds.), Die Veränderung der Kulturlandschaft: 11-31. Münster.

Everett, S. \& C. Aitchison. 2008. The Role of Food Tourism in Sustaining Regional Identity: A Case Study of Cornwall, South West England. Journal of Sustainable Tourism 16 (2): 150-167.

Hofinger, G. 2001. Formen von "Akzeptanz" Sichtweisen auf ein Biosphärenreservat. Umweltpsychologie 5 (1): 10-27.

Ipsen, D. 1993. Regionale Identität - Überlegungen zum politischen Charakter einer psychosozialen Raumkategorie. Raumforschung und Raumordnung 1: 9-18.

Job, H. 1996. Großschutzgebiete und ihre Akzeptanz bei Einheimischen - Das Beispiel der Nationalparke im Harz. Geographische Rundschau 48 (3): 159-165.

Kühne, T. \& T. Behnen 2006. Gibt es eine Rhöner Identität? Empirische Untersuchung des Regionalbewusstseins. Beiträge Region und Nachbaltigkeit 3 (3): 82-88.

Karthäuser, J.M. 2009. Die Biosfera Val Müstair - Parc Naziunal: Zur Akzeptanz des geplanten UNESCO-Bisophärenreservats. In: Mose, I. (ed.), Wahrnehmung und Akzeptanz, von Großschutzgebieten: 83108. Oldenburg.

Leitinger, G., J. Walde, R. Bottarin, G. Tappeiner \& U. Tappeiner 2010. Identifying significant determinants for acceptance of nature reserves: a case study in the Stilfserjoch National Park, Italy. eco.mont 2 (1): 15-22. infas/DLR 2010. Mobilität in Deutschland 2008. Bonn/Berlin.

Mose, I. 2009. Akzeptanz, Einstellung und Image als Einschlussgrößen von Großschutzgebieten. Einige theoretische und methodische Vorüberlegungen. In: Mose, I. (ed.), Wahrnehmung und Akzeptanz von Großschutrgebieten: 9-35. Oldenburg.

Müller-Hohenstein, K. \& A. Abate 2009. Forest Conservation in the Tropics - a Case from Ethiopia. eco.mont 1 (1): 15-22.

Rumpolt, P.A. 2009. Das Selbstbild im Biosphärenpark Großes Walsertal. In: Coy, M. \& N. Weixlbaumer (eds.), Der Biosphärenpark als regionales Leitinstrument Das Große Walsertal im Spiegel der Nutzer. 43-62. Innsbruck. v. Ruschkowski, E. 2010. Ursachen und Lösungsansätze für Akzeptanzprobleme von Großschutzgebieten am Beispiel von zwei Fallstudien im Nationalpark Harz und im Yosemite National Park. Stuttgart.

Schaal, P. 2009. Synthese der Fallbeispiele: Zukunftsperspektiven der Schutzgebietsplanung. In: Mose, I. (ed.), Wabrnehmung und Akezeptan₹ von Großschutzgebieten: 199-214. Oldenburg.

Schieber, K. 2009. Analyse zu Akzeptanz und Image des geplanten UNESCO-Biosphärenreservates Mittlere Schwäbische Alb. In: Mose, I. (ed.), Wahrnehmung und Akreptanz von Großschutzgebieten: 59-81. Oldenburg.

Sieberath, J. 2007. Die Akzeptanz des Nationalparks Eifel bei der lokalen Bevölkerung - Eine empirische Untersuchung zur Verankerung eines Großschutzgebietes in der Region. Bonn.

Stoll, S. 1999. Akzeptanzprobleme bei der Ausweisung von Großschutzgebieten. Frankfurt.

Wallner, A., N. Bauer \& M. Hunziker 2007. Perceptions and evaluations of biophere reserves by local residents in Switzerland and Ukraine. Landscape and Urban Planning, 83: 104-114.

Weichhart, P. 2007. Humanökologie. In: Gebhardt, H., R. Glaser, U. Radtke \& P. Reuber (eds.), Geographie - Physische Geographie und Humangeographie: 941-949. München.

Weixlbaumer, N. \& M. Coy 2009. Selbst- und Fremdbild in der Gebietsschutzpolitik. Das Beispiel des Biosphärenparks Großes Walsertal/Vorarlberg. In: Mose, I. (ed.), Wabrnehmung und Akzeptanz von Großschutagebieten: 37-57. Oldenburg.

Wittmann, D. 2006. Heimat und regionale Identität - pädagogische Möglichkeiten von Bildungs- und Kultureinrichtungen. Beiträge Region und Nachbaltigkeit 3 (3): 78-81.

\section{Author}

\section{Tobias Behnen}

Human geographer. Doctoral thesis on the socio-economic impacts of accelerated sea-level rise, followed by research about air transport and about protected areas. Fellow of the Royal Geographical Society.

Georg-August-Universität Göttingen, Geographisches Institut, Goldschmidtstr. 5, 37077 Göttingen, Germany tbehnen@uni-goettingen.de http://www.uni-goettingen.de/de/129057.html 